\title{
Love Is As Ethical Love Does
}

\author{
SHI Xuan, CHEN Xi \\ Hunan University, Changsha, China
}

\begin{abstract}
In their article “Love Is As Ethical Love Does”, CHEN Xi and SHI Xuan discuss Toni Morrison's Love and assert that this novel is essentially an ethical tragedy of black women. From the perspective of ethical literary criticism, they analyze the dislocated ethical identity of the two main heroines and alignment of their ethical choices to illustrate that other than race and gender, Heed's and Christine's tragedies originate from their uncontrollable irrational will. ${ }^{1}$ Moreover, this novel lays stress on love regarded from an ethical perspective, illuminating "we choose to love", that is, to love while bearing in mind the importance of ethical order and moral norms. Thus, this novel offers moral enlightenment for black women in the process of pursuing love, equality and of reconstructing their ethical identity.
\end{abstract}

Keywords: Love, Toni Morrison, ethical identity, ethical selection

\section{Introduction}

Toni Morrison won the Nobel Prize for Literature in 1993 for her "novels characterized by visionary force and poetic import, gives life to an essential aspect of American reality” (Heinze \& Lewis, 1994, p. 177). As a black woman writer, she epitomizes the contradictions and spiritual predicaments within black communities in her novels, of which the protagonists are mostly black women. Love, Morrison's eighth novel published in 2003, is no exception. Though entitled "love", this novel is "structured around acts of rape in a black family and is unified by anxiety about rape” (Roynon, 2007, p. 33). In this novel, Morrison not only explicitly addresses twenty-first-century debates about black families, but also "draws a correspondence between contemporary debate about the nature of the present crisis in African American communities and earlier uplift discourses" (Carden, 2011, p. 131).

Since its publication, Love has provoked mixed reactions amongst scholars both at home and abroad. Studies are centered on the themes reflected in this novel, such as the consciousness of women, patriarchal hegemony, human predicaments, etc., mostly in terms of psychoanalysis, culture studies or feminist narratology. In elucidating and deconstructing the entanglement of love and hatred between the two heroines Heed and Christine, James M. Mellard, from his psychoanalytic reading, analyses the narcissistic identification of Heed and Christine to elaborate "the paradox of love and identification" in family (Mellard, 2009, p. 706), while Jean Wyatt employed a new perspective on Freud's model of Nachtraglichkeit to explain that the irreparably damaging break with Heed's and Christine's childhood love from which they never recover recapitulates the

SHI Xuan, Postgraduate, College of Foreign Language and International Education, Hunan University.

CHEN Xi, Ph.D., Professor, College of Foreign Language and International Education, Hunan University.

${ }^{1}$ A major concept of ethical literary criticism. It refers to irrational driving force of emotion and behavior such as affections, instinct, hallucination, sub-consciousness, faith, belief, desires, which are not controlled or restrained by rationality (see NIE, 2014, p. 251). 
discontinuity at the heart of female development (Wyatt, 2008, p. 213). Scholars also elaborated on the social ideology and black male authority represented by the protagonist Cosey. Some of them argue that "the novel unfolds against the backdrop of the class differences within the African American community and the social changes brought about by the Civil Rights movement” (Vega-Gonzalez, 2005, p. 277), while other reviewers pointed out that the patriarchal hegemony, repudiated as "problematic legacy needed to be acknowledged and disrupted” (Morris, 2013, p. 320), should be altered with “the maternal solution” (Mellard, 2009, p. 241) or an alternative model of masculine leadership with more “egalitarian measures” (Morris, 2013, p. 335) like Sandler. Although these approaches make some exploration, the inner turmoil and ambivalence of disprivileged black woman tethered and threatened by male-dominant African American community received less critical attention. This article endeavors to uncover that Love is a masterpiece of familial ethical tragedy which is caused not only by domestic oppression of racial persecution and sexual discrimination, but also by the internal confusions of ethical identity within the black community. The protagonists' ethical choices made during their dilemma of ethical identity lead to their violation of moralities and ethical order.

Love is always a main theme in Morrison's novels as she acclaimed in an interview:

I'm writing about love or its absence. Although I don't start out that way. ...But I think that I still write about the same thing, which is how people relate to one another and miss it or hang on to it...or are tenacious about love. (Bakerman, 1979, p. 541)

Love, as Morrison interpreted it, is about the interrelationship of people, and Love is a case in point, which dramatizes the ethical relationship between two heroines, Heed (the Night) Johnson and Christine Cosey. Heed and Christine are childhood friends and turns rivals after Christine’s grandfather, Bill Cosey, marries Heed, who is eleven-year-old. Since Heed became the child-bride, her ethical relationship with Christine had been transformed from friendship to kinship. They hold decades of bitter enmity to each other as they struggle for supremacy and prove themselves as the "sweet Cosey child” (Morrison, 2005, p. 89) for his inheritance, until they ultimately realize and acknowledge that "[they] could have been living [their] lives hand in hand instead of looking for Big Daddy everywhere” (Morrison, 2005, p. 189). The spoilt female friendship and the final triumph of female bonding between Heed and Christine illustrate Morrison's meditations on love, ethics and accountability: love is as ethical love does and comes as a result of moral effort.

\section{Heed: Confusion of Ethical Identity}

As Bell Hooks asserts in her All About Love: New Vision:

...black women are in an unusual position in this society, for not only are we collectively at the bottom of the occupational ladder, but our overall social status is lower than that of any other group. Occupying such a position, we bear the brunt of sexist, racist, and classist oppression. (Hooks, 2000a, p. 16)

Therefore, as a triply victimized demographic, black females have to unite together like families to cope with oppression and to alleviate their suffering during their initiation in a paternalistic society. Toni Morrison once made a speech at Sarah Lawrence College that "the loneliest woman in the world is a woman without a close woman friend" (Smith, 1983, p. 99), and she attaches great importance to sisterly friendship in her novels, which "is special, different, and has never been depicted as the major focus of a novel before Sula" (Tate, 1994, p. 157). Before Sula, "relationships between women were always written about as though they were subordinate to some other roles they're playing” (Tate, 1994, p. 157), while in Love, Women's friendship becomes a pivotal one in all relationships. 
According to Koppelman's elucidation, women's friendship refers to:

...a rich, complex, archetypal relationship. Although friendships can vary infinitely, certain things must be part of their content. One thing that must be there is recognition of the need for reciprocity in the relationship. There must also be the opportunity for reciprocity. Finally, there must be a balance of power or privilege between or among the participants in the relationship. That is, the friends must be equally in and subject to each other's power. (Koppelman, 1991, p. 280)

The "reciprocity" best sheds light on the reason for the early attachment, the innocent friendship of Heed and Christine. Heed and Christine, though born in different classes, have one thing in common —a deficiency of love. As Morrison puts in the "Foreword" to Love: "For the most thing Christine, Heed and Junior have already lost,... are a father and a mother, or to be precise, fathering and mothering” (2005, p. x), the ethical relationship between parents and children in these girls' family is abnormal due to parental neglect. Heed is the youngest of seven children in a poor and ostracized family, in which the parents are lazy and "thought sitting in a rowboat with a string was work" (Morrison, 2005, p. 138), moreover, they are indifferent and apathy to their own children, for example, they choose at random the names for their children "overblown names people give to mules and fishing boats, Bride, Welcome Morning, Princess Starlight, Righteous Spirit, Solitude, Heed the Night” (Morrison, 2005, p. 138); instead of grieving over the death of their two drawn children, they take advantage of people's sympathy of their loss like "a begging cup” (Morrison, 2005, p. 138) to get money. When Cosey wants to marry 11-year-old Heed, her parents "[give] her up like they would a puppy” (Morrison, 2005, p. 105), and "let their youngest girl marry a fifty-two-year-old man for who knew how much money changed hands" (Morrison, 2005, p. 138). From her parents, who "swarm and bite for blood" like "fire ants for family" (Morrison, 2005, p. 127), Heed could not possibly get proper ethical enlightenment, since "morals of any kind whatsoever are not know in that family. What would Heed, who got married at the ripe old age of eleven, know about morals, restraint...” (Morrison, 2005, p. 145). In this sense, she is irrevocably cut off from traditional morality and ethical norm at root, which foreshadows her abuse impinge and violation. Without a protective mother and a supportive father, "alone" is the most indelible impression on her days with her family, until she meets Christine who "fought for her", "protect her", "give her clothes: dresses, shorts, a bathing suit, sandals" (Morrison, 2005, p. 132), in some sense, Christine presumably provides a maternal relationship that Heed does not experience with her mother. Christine, on the other hand, is born in an affluent family, and her grandfather Cosey owns Hotel and Resort which "was the best and best-known vacation spot for colored folk on the East Coast” (Morrison, 2005, p. 6). Christine's mother, May, is keener on money and the family's hotel-resort business than her daughter Christine, and even weans Christine at three months. After Christine's father, Billy Boy, dies at 24 when Christine is five years old, the widowed May largely ignores Christine in favor of managing the hotel business, so much so that Christine admits that "May wasn't much of a mother" to her (Morrison, 2005, p. 184). With a father lost and a distant mother, Christine struggles to find love, solace and acceptance, but seems at about seven or eight years old to discover her salvation in Heed. When Heed and Christine meet for the first time on the beach, they "experience identificatory moment" (Mellard, 2009, p. 703) which catalyzes deep friendship like sisters who accompany, care about and support each other. Ethically speaking, their friendship is a kind of social relationship, so in order to make this bond as tight as a blood tie, Heed agrees to marry Cosey, Christine's grandfather, hoping strengthen her friendship with Christine in a deviant way. However, Heed's attempt dramatically changes their ethical relationship and ignites wars for defending their ethical identities, which consequently point the way to their ruination. 
A new ethical relationship, or more specifically speaking, a kinship, has been established through Heed's marriage to Cosey. This marriage, which transforms Heed's ethical identity from friend to grandmother for Christine, disequilibrates the "balance of power or privilege" (Koppelman, 1991, p. 280) between Heed and Christine in their friendship, with Christine's unilateral subjection going to Heed. As "ethics requests ethical identity's accordance with moral behavior, in another word, the consistency of identity and behavior under the ethical principles" (NIE, 2014, p. 64), the identity confusion of Heed and Christine gives rise to ethical conflicts between them, "since ethical identity is inextricably linked to ethical rules, the changes of character's ethical identities are bound to arouse ethical chaos and conflicts" (NIE, 2014, p. 256). In order to hold on to her new ethical identity in the family, Heed's irrational will takes a firm control over her rational will, as a result, her animal instincts prevail so much as to attempt to murder Christine, her granddaughter-in-law, and to forge a will to inherit Cosey's legacy. With the degeneration of morality and transgression of ethical rules, Heed's tragedy is assured.

Heed's tragedy stems from her lack of ethical consciousness. Heed marries Bill Cosey, Christine's grandfather, when she is only eleven years old for two reasons. The first reason is, the marriage is at Cosey's will, who fondles prepubescent Heed and chooses her to be his wife. In a patriarchal society, women are instructed to obey and please men. Therefore, underage as she is, molested by a 51-year-old adult, a community leader who is supposed to protect the black community, she has to marry him, for he, "the Big Man who, with no one to stop him, could get away with it and anything else he wanted” (Morrison, 2005, p. 133), needs a girl who is young and pure enough to conceive an heir. Within such an ethical environment, it is socially acknowledged and accepted for a pedophile to marry an 11-year-old girl, and people "forgave Cosey. Everything. Even to the point of blaming a child for a grown man's interest in her” (Morrison, 2005, p. 147). Though he does not in fact rape Heed, he indeed commits "heroic sexual violence" (Roynon, 2007, p. 45) and fails to set an ethical model for an innocent preteen during the time when Heed's ethical consciousness is being established. The second reason is: this marriage is Heed's own choice. Some scholar interprets Heed's marriage with Cosey as that she "escapes her family through marriage, but more immediately she manages a psychological escape through narcissistic identification with Christine” (Mellard, 2009, p. 703), because "Christine represents what Heed wishes to be" (Mellard, 2009, p. 703). Given Heed was so desperate to be as equal as Christine and to obtain what Christine had owned by marrying Christine's grandfather, she couldn't have had a free and equal friendship with Christine at the very first. Her purpose of marrying Cosey is in the hope of consolidating her friendship with Christine into an unalterable family tie, as she confesses to Christine: "I wanted to be with you. Married to him, I thought I would be” (Morrison, 2005, p. 193).

Although Heed is a victim of this marriage, no one accepts her or sympathizes with her, on the contrary, people in the community demean her for "Cosey's status as a patriarch and a leader trumps any recognition or admonition of his bad behavior because of a reductionist view of the power and privilege of leadership" (Morris, 2013, p. 329). Isolated and abused, Heed needs friendship more than ever, but this marriage alters her ethical relationship with Christine from a friend to a grandmother, and the two girls will not be friends any longer. Not surprisingly Heed fails to identify herself with concomitant obligations. Under normal circumstances, children gain the ethical consciousness during their growth through enlightenment and education, but for Heed, she "had no schooling, no abilities, no proper raising” (Morrison, 2005, p. 72), and her neglecting parents could not give her moral and ethical enlightenment or instruction, or help her clarify ethical identity, let alone her pedophilia husband, so she fails to identify herself both as the wife of Cosey and the 
grandmother of Christine as well. Therefore, after she marries Cosey, she treats Christine, her granddaughter, like a friend as before her marriage, such as: asking Christine to wear her wedding ring, inviting Christine to join their honeymoon trip, which are obviously ethically inappropriate as "threat of incest" (Harack, 2013, p. 264). Although she manages to strengthen her friendship with Christine, but all her redeeming reconciliation is rebuffed by Christine with harsh comments and smirk. When Christine shouts at her with secret language of their own, "Ou-yidagay a ave-slidagay! E-hidagay outht-bidagay ou-yidagay ith-widagay a ear's-yidagay ent-ridagay an-didagay a andy-cidagay ar-bidagay!” (Morrison, 2005, p. 129), Heed feels denied and abandoned by her friend, so her hatred sprouts. Christine's venomous words cuts off Heed's bounding to Christine, just as Mellard asserted “...if for a child whom her parents named Heed the Night the best moment of her life was that on the beach when she met her identificatory other in Christine, surely this moment, when her other denies her, is the worst” (Mellard, 2009, p. 709).

Therefore, when her endeavor on reconciliation is repelled by Christine, she plunges into anxiety about her ethical identity. Overshadowed by helplessness and anxiety, she starts to find refuge in the men's world to compete with Christine for something else-man's love. In Christine’s 16th birthday party, Cosey spanks Heed in public, “took his granddaughter's side against his wife's” (Morrison, 2005, p. 134). As for Christine, what she remembers is her triumph over her competitor, "the flood of pleasure that came when he took his granddaughter's side against his wife’s” (Morrison, 2005, p. 134), while as for Heed, who solely identifies herself as Cosey's newly wedded bride with privileges and higher status than Christine, feels ashamed and threatened by Christine. To take revenge on Christine, Heed sets fire to Christine's mattress attempting to kill her. As Cosey's wife, Heed, at the same time, is Christine's grandmother, so her attempted murder of her granddaughter, a sisterly friend as well, is a crime against ethical taboo. The confounding of double identities as grandmother and friend of Christine makes Heed discard rational will in her ethical choices, and consequentially she unscrupulously vies with Christine for property.

Heed's life after the marriage is no better than before marriage, because she "never really feels secure or loved" (Carden, 2011, p. 139). Throughout her life, she contrives to identify herself as a qualified wife of Cosey so as to secure her position appended to this marriage. She knows by nature that financial power is a symbol of dominance, as she has a "flawless memory" and is "highly numerate", so "money she grasped completely" (Morrison, 2005, p. 75), but later she reckons the most effective way to protect herself is to have an heir, the ultimate guarantee of her position, otherwise she will be driven out of her own house by May and Christine. When she is 25 years old, in order to get a son, she has an extramarital affair and is pregnant which she believes the unborn baby "was a son, she was sure, and had he been born she wouldn't need to sneak off, driven by an untethered teenager to a collapsing hotel in order to secure her place” (Morrison, 2005, p. 174). To her disappointment, her pregnancy ends up with miscarriage with "a single instance of spotting” at first and then "heavy clotting” (Morrison, 2005, p. 173), as a result, she is alienated by her husband for her infertility.

As "intense spiritual and emotional lack in our lives is the perfect breeding ground for material greed and overconsumption” (Hooks, 2000a, p. 105), emotionally insecure as Heed is, Heed needs the guarantee of property to prove and consolidate her position in family, so she instigates a war for Cosey's legacy. When Coesy dies in 1972, his ambiguous will triggers a war for inheritance which is essentially a war for ethical identity, because it is difficult to judge who is the "sweet Casey child" (Morrison, 2005, p. 89), the inheritor. Both of Heed and Christine are justified to identify themselves as Cosey's child, for "Heed's claim was strong-especially since she called her husband Papa. Yet since, biologically speaking, Christine was the 
schoolchildren, her claim of blood was equal to Heed's claim as widow” (Morrison, 2005, p. 88). In order to deprive Christine of the inheritance, Heed hires a girl to forge Cosey's will to take her claim to Cosey's fortune, because her irrational will surpasses her rational will, and she casts aside her responsibility that her ethical identity conferred. According to law, forging wills is an illegal act, an act breaking the ethical norm as well, which could not be a legitimate evidence of her identity as the "sweet Cosey child" (Morrison, 2005, p. 89) to inherit the legacy. With the forged will, she is neither a virtuous wife to Cosey nor a fit grandmother to Christine. When she is forging a new will in the attic of their deserted old hotel, she falls down the stairs and is dying. Her illegal and unethical behavior is the aftermath of her prevalent irrational wills and identity misalignment. Her unethical behavior violates the ethical order and her punishment is doomed. The punishment-her death—is the testament to the importance of the accordance of ethical identity and ethical codes, otherwise, ethical chaos will definitely cause the violation of ethical order, for which, one has to pay the price, light or heavy, to reconstruct the ethical order.

\section{Christine: Failure of Reconstruction of Ethical Identity}

When Heed and Christine first meet on a beach and share one ice cream, their friendship, which is so profound as to be proclaimed as first love, is established. Regardless of social bias on class, Christine makes friends with Heed, and she

...defied her mother to protect her (Heed), to give her clothes: dresses, shorts, a bathing suit, sandals; to picnic alone on the beach. They shared stomachache laughter, a secret language, and knew as they slept together that one's dreaming was the same as the other one's. (Morrison, 2005, p. 132)

As Morrison reveals in a later chapter, Christine is in an antithetic position to her mother-May-who neglects her and acts as an accomplice with Cosey, and who ostracizes her from family love. In a male-dominant society, May dismantles her maternal responsibility for men’s affection, and “(h)er whole life was making sure those Cosey men had what they wanted. The father more than the son; the father more than her own daughter” (Morrison, 2005, p. 102). May’s negligence of maternal love pushes Christine to Heed and agitates Christine's protection for Heed.

Although May doesn't spend much time with Christine, a faithful Christian as May is, she might potentially give Christine ethical enlightenment, so when Christine happens to espy Cosey indecently assaulting Heed, "she is ashamed of her grandfather and of herself" (Morrison, 2005, p. 193). She acknowledges her grandfather's molestation of a child, who she regards as a younger sister, is a shame, an incestuous behavior. After this event, she "can't look at Heed", and estrangement arises from "this particular shame” that "could not tolerate language” (Morrison, 2005, p. 193), because Heed is catapulted untimely into the world of adult sexuality and marriage where Christine think it is ethically improper. Later, Heed marries Christine's grandfather, disintegrating their reciprocal friendship, but forcing them into kinship. Christine regards this marriage as Heed's betrayal to their friendship and Heed's conspiracy for her family property, as she condemns Heed:

We were best friends. One day we built castles on the beach; next day he sat her in his lap. One day we were playing house under a quilt; next day she slept in his bed. One day we played jacks; the next she was fucking my grandfather. One day this house was mine; next day she owned it. (Morrison, 2005, p. 131)

Although Heed tries to share her honeymoon story and offers her wedding ring to Christine, Christine 
takes Heed's friendly gestures as ridiculous remedies to make up for her betrayal against their friendship, so she holds rancor toward Heed, such as jeering at Heed's dressing, picking her grammar or even insulting her in their secret language. In fact, all these hostile provocations stem from her denial of her new ethical identity as well as that of Heed's. The change of ethical identity perplexes her, because she cannot treat Heed, who was once her guest and playmate under her protection, as a sisterly friend anymore, neither will she accept Heed as her grandmother.

Heed's marriage with Cosey not only changes Christine's ethical identity, but also exiles Christine from her family. This confused ethical identity leads to hostile conflicts, which, without exception, ends in failure of Christine who forces her grandfather to pick a side from heterosexual love and kinship. She wants to consolidate her position through her grandfather's defense for her against Heed, so to deny Heed's position in the family. Her first provocation is her running away after Heed's honeymoon, but her action cannot change the fact: Heed is the bride of Cosey. Although at this time Heed still treats Christine as her dearest friend, Christine cannot treat Heed as Heed treats her, so when Heed returns from her honeymoon offering Christine to wear her wedding ring, Christine curses her in great wrath. Why does Christine react so furiously to a ring that Heed takes just as a beautiful jewelry to share with her friend? It is because Christine is better educated than Heed; her ethical consciousness tells her that wedding ring is the symbol of identity and power, thus Heed's wedding ring is the symbol identifying her new ethical identity that she is the lawful wife of Cosey, mother-in-law of May and grandmother-in-law of Christine. Christine hates Heed for her betrayal to their friendship and for presenting herself as a hostess of her family, so she rejects the reality by running away from home indignantly. When she returns from her runaway, Christine is hurt less by the slap by her mother than by Heed's reaction: "Heed did not speak one word to her. Instead, she stood on the stairs with papa and took his hand in hers" (Morrison, 2005, p. 129). Heed's seemingly silence is an explicit declaration of position, or a reiteration on Christine's failure as well. Later, catering to Cosey’s intention to separate Christine and Heed, Christine is sent to Maple Valley School, where Christine had been deserted for three years by her family, especially by her mother, and Christine assumes that Heed is the very one to blame. The second provocation takes place on Christine's 16th birthday in Cosey's hotel. In that birthday party, Christine and Heed have a fight, but Cosey taking Christine's side spanks Heed. Just when Christine seethes herself in her triumph, she is once again the one to be sent away from family. Although Christine turns "sixteen-year-old, poised and ready to take her place in the family, they threw her away, because by then Heed had become grown-up-nasty” (Morrison, 2005, p. 133), and because the patriarch and matriarch, her grandfather and her mother, desert her. As Christine says, what Heed is doing in her whole life is "replacing me, getting rid of me. I'm always last; all the time the one being told to go, get out” (Morrison, 2005, p. 95). Her two provocations accentuate her anxiety of her ethical identity and the efforts for restoration of her position overthrown and replaced by Heed.

Christine's frustration of ethical identity in family pushes her to seek a better acknowledged social identity through Civil Rights movement. She commits herself to the civil rights movement which aims at fighting for more legitimate rights and equality for black people, but her attempt turns out to be a failure more than a normative triumph. Morrison once commented on Civil Rights movement:

I was trying to complicate the civil right progress, interrogating it in a new way so that we would not be left with the simple notion that there was some agitation, some pain and then, now, everybody moved into whatever neighborhoods they want to and there was more access into the corridors of power, there was more money, you know better jobs, etc., none of which is not true, but that's not the full story. (Morrison \& West, 2004, p. 20) 
More than deconstructing Civil Rights movement, Morrison specifically elucidates Christine’s disillusion to construct her social identity for the reason that no one "can successfully attack issues such as racism or other systems of dominance in the public sphere without challenging sexism in one's own relationships” (Morris, 2005, p. 331). For love, Christine cohabits with an activist called Fruit, for whom she has abortions seven times, sacrificing her right to be a legal wife and mother. For seven years, she had had great faith in the Civil Rights movement, establishing her identity as a contributor to the movement, a valuable participant of it, "not the disrupting wife, the surplus mistress, the unwanted nuisance daughter, the ignored granddaughter, the disposable friend" (Morrison, 2005, p. 164). It is not until a rape of a seventeen-year-old volunteer when Christine comes to realize that, though this movement has succeeded in demolishing racial segregation system legitimately, it casts side the interest and wellbeing of black women. In the civil rights community, the raped girl is blamed as a temptress, while the rapist is unpunished foregrounding his contribution to the movement, thus "the girl's violation carried no weight against the sturdier violation of male friendship" (Morrison, 2005, p. 166). The rape accidence initiates the collapse of the relationship of Christine and Fruit who defends the assault, and makes Christine aware of the fact that she herself is also marginalized both as a black and a woman. Christine fails in constructing her social identity as she expects, because there always exists conformity in gender with distinction in race, and conformity in race with distinction in gender. According to the investigation of Barnett, it is true that "black women in their homes, churches, social clubs, organizations, and communities throughout the South performed valuable leadership roles during the modern Civil Rights movement in the United States” (Barnett, 1993, p. 177), but their leadership is not recognized by black males, let alone an ordinary follower like Christine.

Set back by the outside sociality, Cosey's will gives Christine an opportunity of retrieving and reestablishing her ethical identity in her family. At Cosey's funeral, Christine has a big fight with Heed because Christine tries to put rings on dead Cosey's fingers, in which instance, "the rings display Christine's desperate desire to prove that she is the sole inheritor of Cosey's power and capital” (Wardi, 2005, p. 208). She is indeed the only legal blood relatives of Cosey as the "sweet Cosey child" (Morrison, 2005, p. 89). Tortured by the dilemma of ethical identity for years, Christine, in 1975, "pushed her way into the house flashing diamonds and claiming it as hers" (Morrison, 2005, p. 80), thus the war for re-claiming ethical identity erupts. "Sweet Cosey child” (Morrison, 2005, p. 89) reminds Christine of her ethical identity as Cosey's granddaughter, so she has every right to inherit Cosey's property - the house. As a matter of fact, when she comes back home, she is abandoned by her comrade of the Civil Rights movement, dumped by her lover Doctor Rio who kept her for three years after her breakup with Fruit, and all she has is her insignificant clothes. According to Maslow, there is a hierarchy of people's needs: physiological needs, safety needs, love and belonging, esteem and self-actualization, in which "physiological needs are the most proponent of all needs” (Maslow, 1992, p. 36). Moreover, Maslow further elaborates that "if all the needs are unsatisfied, and the organism is then dominated by the physiological needs, all other needs may become simply nonexistent or be pushed into the background" (Maslow, 1992, p. 37). To satisfy her physiological need, Christine chooses to come home and to take back what belongs to her but has long been taken away from her. To be more specific, she vies for the legacy with Heed, her grandmother. After Christine returns home, she and Heed have lived together for nearly 20 years. In fact, Christine takes care of Heed in all these years, because Heed has become an arthritic recluse. Under the same roof, Heed, namely the grandmother of Christine, can only watch helplessly as Christine usurps Cosey's legacy, planning to drove her pennilessly from her own home. Christine holds the supremacy until Heed 
recruits Junior to assist her in her machinations against Christine, scheming to forge a new will, one to be found on a resort menu in Cosey's former resort at Sooker Bay. Christine senses the crisis of being replaced again, as she said "she is replacing me" (Morrison, 2005, p. 95). Facing the threat of Heed, Christine becomes more determined to reconstruct her ethical identity as the master of family.

Christine puts aside her ethical identity as granddaughter, as a result, she has difficulty in making ethical choice through confirmation of her identity as well as Heed's after Heed marries her grandfather. The ethical environment Christine lives in, in which black women are triply victimized by gender, race and class failure, makes it impossible for her to reconstruct an new ethical identity at home as well as in the society, in her youth as well as in her later years.

As Morrison writes in the "Foreword" of Love, "I became interested in the manner in which African Americans handled internecine, intraracial betrayals, and the weapons they chose in order to survive them" (2005, p. xi). Undoubtedly the weapon is love, as the title of this novel suggests. Erich Fromm defines love as "the will to extend one's self for the purpose of nurturing one's own or another's spiritual growth" (Hooks, 2000a, p. 4). He further explains that "Love is as love does. Love is an act of will—namely both an intention and an action. Will also implies choice. We do not have to love. We choose to love” (Hooks, 2000a, p. 4). Likewise, Morrison continuously probes into this topic stating that love is not merely an emotion, but a choice, because people "don't know the real kinds, the better kinds, where losses are cut and everybody benefits. It takes a certain intelligence to love like that—softly, without props” (Morrison, 2005, p. 63). What Morrison means is that "love comes as a result of conscious effort" (Alexandru, 2008, p. 202), moreover, love is a choice that needs intelligence, a choice under the control of rational will.

Though the novel is entitled "love", it is replete with rape, betrayal, fear, child abuse, and pedophilia, while the word "love" is absent in the novel on purpose, with the exception of the times at the end of the novel, articulated by Heed, who gains her epiphany when death comes to her, "Love. I really do" (Morrison, 2005, p. 194). It is obvious that the "love" she articulates is a verb, an act to choose. Anissa Janine Wardi in A Laying on of Hands: Toni Morrison and the Materiality of Love argues that Fromm's definition of love "cannot be used to describe any relationship in Morrison's latest novel” (Wardi, 2005, p. 216), however, from the perspective of ethical literary criticism, love can be used to describe the relationship between Christine and Heed, for Heed articulates "love" at the last moment as a determination to give love. Since "abuse and neglect negate love" (Hooks, 2000a, p. 22), what Heed and Christine do to each other in fifty years is not deserved to be called "love", so the word "love" barely appears until the end of the story, just before Heed's death when they show their decision to affirm love.

Due to the premature marriage of Heed, the two little girls are trapped into ethical identity predicament and are "locked into a system of meaning that robbed girlfriend love of value and made the only love that signifies the love of man” (Wyatt, 2008, p. 198). To be more specific, they betray each other for Cosey's love. As Toni Morrison once said in an interview:

I was interested in the way in which sexual love and other kinds of love lend themselves to betrayal. How do ordinary people end up ruining the thing they most want to protect? And obviously the heart of that is really the effort to love. (McKinney-Whetstone, 2003, p. 206)

In the case of Heed and Christine, the reason they "ruin their love" and "lend themselves to betrayal" is that they are confused about their new ethical identities, and don't make right ethical choices. Heed's marriage 
with Cosey is her ethical choice, while Christine’s running away from Cosey's home flinging herself into Civil Right movement is also her ethical choice, both involving the problem of ethical identity. Ethical identity defers humans from animals, and deciphers the secret code of human nature in the light of values, responsibility, obligation, and morality. A person should have at least one ethical identity, and once his or her ethical identity is established and acknowledged, he or her thereby should act in accordance with the moral norm and responsibility attached to this ethical identity. View in this light, Heed has accepted her ethical identity as Cosey's wife, but in the meantime, she subconsciously acknowledges her ethical identity as Cosey's "child", referring Cosey everywhere in the novel as "Papa", while paradoxically she regards and loves Christine as a girl friend not a grandmother. As far as Christine is concern, she totally rejects her ethical identity as Heed's granddaughter and Heed's ethical identity as Cosey's wife, she can neither love Heed as a friend does nor as a granddaughter does. Since love is bounded by duty and obligation, true love is an ethical choice to do right things bounded by rational will and with a clear sense of ethical identity.

\section{Love's Ethical Essence}

At the end of the novel, before the death of Heed, Heed and Christine make reconciliation like old friends talking about idyllic moments in their childhood. Echoing Sula, Morrison's most sustained exploration of the profundity of female companionship, in which "Nel ... realize that the great loss she has suffered is really the destruction of their friendship, the one chance they had to learn to be full, complete women" (Bakerman, 1981, p. 553), Love ends up with Heed and Christine's epiphany_- "We could have been living our lives hand in hand instead of looking for Big Daddy everywhere” (Morrison, 2005, p. 189), which "sums up both their recognition of the wrong turn their lives took and the cause of that disastrous deviation” (Wyatt, 2008, p. 198). When Heed and Christine look back on their early friendship, reflecting on the pre-heterosexual world from a new perspective, they come to realize that "cause of that disastrous deviation" is the enormity of Bill Cosey's actions done to 11-year-old Heed, as Heed herself denounces: "He took all my childhood away from me" (Morrison, 2005, p. 194). The patriarchal heterosexuality and premature marriage force Heed and Christine’s attention swerve from their friendship to papa's favor, and initiate their fifty-year enmity. Their epiphany indicates that they have realized that sisterly love between females can help them gain freedom, spiritual peace, and redemption in a patriarchal context. Therefore, when Heed approaches death in the old resort hotel, Heed and Christine regret they "never found their true selves or they never found the love their hearts longed to know" (Hooks, 2000a, p. 198). Heed's dying is a trigger for both herself and Christine to reflect on deficiency of love in their life, and on how to perform in an ethical way of practicing the art of love they fails during the past fifty years. They open their hearts and have a reminiscent conversation about all the loving experiences they have ever shared. It is love that restrains their irrational wills from conspiring and "nurtures spiritual growth of each other” (Hooks, 2000a, p. 13). In this light, their love is as much a kind of moral emotion controlled by rational will which is different from the heterosexual love of Cosey, Fruit, or any other man, who, controlled by irrational will and sexual desire, do great harm to females in the name of love. At the end of the story, the scenario of their first meeting reappears when they truly loved each other at the first time. Heed's death deconstructs the man-centered world in which women are trapped and forced to revolve around men, and her death reminds them of the love they choose to give:

It's like that when children fall for one another. On the spot, without introduction. If such children find each other before they know their own sex, or which one of them is starving, which well fed; before they know color from no color, 
kin from stranger, then they have found a mix of surrender and mutiny they can never live without. Heed and Christine found such a one. Most people have never felt a passion that strong, that early. (Morrison, 2005, p. 199)

Indeed, Hooks' ideas about love that "love as an action rather than a feeling is one way in which anyone using the word in this manner automatically assumes accountability and responsibility” (Hooks, 2000a, p. 13) reveals the ethical feature of love. During the fifty years of their hostility, Heed and Christine fail to undertake the accountability and responsibility to behave ethically in a kinship structure, vying with each other under the frame of patriarchy first for man's favor, then for man's estate. Their conversation before Heed's death "promises a new beginning. Retrieving the potentials inherent in their childhood love can now generate movement into a creative future. Continuity is reestablished, past, present and future reconnected in a potentially creative collaboration” (Wyatt, 2008, p. 197). Since then, they, as if reborn again, determine to love each other again. As the ethical order breaker-Cosey—is dead, the marriage is over. There is no premature heterosexual assailant, no identity predicament or confusion for Heed and Christine, but only two happy women, who have gained ethical consciousness who love each other all the way for

...no matter what has happened in our past, when we open our hearts to love we can live as if born again, not forgetting the past but seeing it in a new way, letting it live inside us in a new way. We go forward with the fresh insight that the past can no longer hurt us. (Hooks, 2000a, p. 209)

In addition to flogging patriarchy in which the two women protagonists "identifying themselves in relation to Cosey's dark hierarchy of ownership, staking their security, love, and belonging in him, they abandoned other, more celestial possibilities” (Carden, 2011, p. 139), Toni Morrison expresses deep concern about the ethical problem of the most intimate of relationships among people in the ethical environment of post-Civil Rights Era. People in the world, no matter who you are, should live and act ethically:

In actuality, living ethically ensures that relationships in our lives, including encounters with strangers, nurture our spiritual growth. Behaving unethically, with no thought to the consequence of our actions, is a bit like eating tons of junk food. While it may taste good, in the end the body is never really adequately nourished and remains in a constant state of lack and longing. Our souls feels this lack when we act unethically, behaving in ways that diminish our spirits and dehumanize others. (Hooks, 2000a, p. 13)

"Behaving unethically" means violating the moral norms and breaking the ethical order. As in the case of Heed and Christine, when they behave unethically, they act irrationally, and consequently, they are "in a constant state of lack and longing” for man's favor, legacy and power. On the contrary, love ethically means to love while bearing in mind the importance of moral norms and ethical order. Thus, at its very heart, Love endorses that, in the process of pursuing love and equality, ethics plays an important part. No matter how excusable the reason is, should one violate the ethical order and moral norm, he or she would have ended up with tragedy just like Heed and Christine: one deprived of life, the other without offspring, alignment and hope. As "virtually every substantial work of literature engages moral questions, and through these encounters with fictional characters we gain a subtler sense of virtue and vice" (Mark, 2004, p. 21) and "(t)he general aim of literature is to describe the ethical order, the changes of ethical order, and moral problems caused by those changes, so as to offer some experience for human beings to learn from” (NIE, 2014, p. 89), when we read literary works, the fictional characters in literary works provide ethical models or lessons for people. In Love, Heed and Christine's tragedy mainly stems from their dislocated ethical identity, as well as their inappropriate ethical choices, thus this novel "gives moral lessons for people regarding to their real life and spiritual life, and 
offers moral experience for self-fulfillment” (NIE, 2014, p. 14), that is, to love ethically is the right way for black women to build subjectivity and to constitute their identity, which also serves as significant ethical guidance for the entirety of humankind.

\section{Conclusion}

Love reveals the black feminist reality that "individual who fight for the eradication of racism or classism while supporting sexism oppression are helping to maintain the cultural basis of all forms of group oppression. While they may initiate successful reforms, their efforts will not lead to revolutionary change" (Hooks, 2000b, p. 40), and more importantly, it inspires us to probe into the cause of their inferiority and vulnerability. Heed and Christine's tragedy is the result of their confused ethical identity under the multi-oppression of race, class, and gender, which consequentially leads to the violation of ethical orders and is poised to ethical chaos. Thus, this novel reveals in a more profound way of love- "we choose to love” (Hooks, 2000a, p. 4)—people "have already chosen to embrace a love ethic, allowing it to govern and inform how we think and act, know that when we let our light shine, we draw to us and are drawn to other bearers of light” (Hooks, 2000a, p. 101). Moreover, the epiphany that "we choose to love" (Hooks, 2000a, p. 4) ethically is a kind of enlightenment for people all over the world in our efforts of pursuing equality and constructing identity in the twenty-first century.

\section{References}

Alexandru, M. S. D. (2008). Love as reclamation in Toni Morrison's Africa American Rhetoric. European Journal of American Culture, 27(3), 191-205.

Bakerman, J. S. (1979). The seams can’t show: An interview with Toni Morrison. Black American Literature Forum, 12, 56-60.

Bakerman, J. S. (January 1981). Failures of love: Female initiation in the novels of Toni Morrison. American Literature, 52(4), 541-563.

Barnett, B. M. (June 1993). Invisible Southern black women leaders in the civil rights movement: The triple constraints of gender, race, and class. Gender and Society, 7(2), 162-182.

Carden, M. P. (Spring/Summer 2011). “Trying to find a place when the streets don’t go there”: Fatherhood, family, and American racial politics in Toni Morrison’s “Love”. African American Review, 44(1/2), 131-147.

Heinze, D., \& Lewis, C. E. (1994). Toni Morrison. In J. R. Giles and W. H. Giles (Eds.), Dictionary of literary biography, volume 143: American novelists since World War II, third series. Detroit: Gale Research.

Hooks, B. (2000a). All about love: New visions. New York: William Morrow and Company, Inc.

Harack, K. (2013). "Not even in the language they had invented for secrets": Trauma, memory, and re-witnessing in Toni Morrison’s Love. The Mississippi Quarterly, 255-278.

Hooks, B. (2000b). Feminist theory: From margin to center (2nd ed.). Cambridge, MA: South End Press.

Koppelman, S. (Ed.). (1991). Women's friendships: A collection of short stories. Norman: University of Oklahoma Press.

Mark, W. R. (2004). Why literature matters in the $21^{\text {st }}$ century. New Heaven: Yale University Press.

Maslow, A. H. (1992). Motivation and personality (2nd ed.). Beijing: China Social Sciences Press.

McBryde, L. D. (2010). The unbroken bond: A qualitative study of sisterhood among African American women. Minneapolis: Capella University.

McKinney-Whetstone, D. (October 2003). The nature of love. Essence, 34(6), 206.

Mellard, J. M. (Winter 2009). “Families make the best enemies”: Paradoxes of narcissistic identification in Toni Morrison’s Love. African American Review, 43(4), 699-712.

Morris, S. M. (Spring 2013). A past not pure but stifled: Vexed legacies of leadership in Toni Morrison’s Love. The South Atlantic Quarterly, 112(2), 319-338.

Morrison, T. (2005). Love. New York: Vintage.

Morrison, T., \& West, C. (2004). Blues, love and politics. The Nation, 18-28.

NIE, Z. Z. (2014). Introduction to ethical literary criticism. Beijing: Peking University Press. 
Roynon, T. (April 2007). A new “Romen” empire: Toni Morrison’s “Love” and the classics. Journal of American Studies, 41(1), 31-47.

Smith, B. (Ed.). (1983). Home girls: A black feminist anthology. New York: Women of Color Press.

Tate, C. (1994). An interview with Toni Morrison. In D. Taylor-Guthrie (Ed.), Conversations with Toni Morrison. Jackson: University Press of Mississippi.

Vega-Gonzalez, S. (2005). Toni Morrison's Love and the trickster paradigm. Revista Alicantina de Estudios Ingleses, 18, $275-289$. Wardi, A. J. (Fall 2005). A Laying on of Hands: Toni Morrison and the materiality of Love. Melus, 30(3), 201-218.

Wyatt, J. (May 2008). Love's time and the reader: Ethical effects of Nachträglichkeit in Morrison's Love. Narrative, 16(2), 193-221. 